\title{
Non-Violent Resistance in Iranian Kurdistan After 1979
}

\author{
Allan Hassaniyan ${ }^{1}$ \\ College of Social Sciences and International Relation, Centre for Kurdish Studies, University of Exeter, UK
}

\begin{abstract}
This paper sheds light on the significance of the 1979 Iranian Revolution for the Iranian Kurdish movement, arguing that the Revolution provided Iranian Kurds with multifaceted opportunities as well as challenges. In the ensuing years, the Kurdish movement entered into a new phase of its rise. With the emergence of numerous civil society organizations and political parties, the Kurdish movement experienced a hitherto unprecedented growth and diversification of actors and organisations. Kurdish civil society flourished drastically, and a significant part of the Kurdish movement's challenge to the newly-established government in Tehran was channelled through collective nonviolent resistance. The creation of city councils (şoray şar) across Kurdistan constituted the first important challenge to the authority of the Provisional Revolutionary Government, whilst the mobilisation of collective non-violent resistance introduced new forms of resistance to the post-Revolutionary authoritarian state's policies in Kurdistan.
\end{abstract}

Keywords: Iranian Revolution, Kurdish movement, KDPI, Komala, Non-violent resistance.

Sheikh Ezzedin Hosseini" "In Kurdistan we know that war is not in our interest, though our opponent decides the methods of our struggle” (Tehran Musavvar, 1979f, pp. 36-37).

\section{Introduction}

With the collapse of the Pahlavi dynasty in 1979, Iran became a battlefield of different groups and communities with competing interests. This situation created a unique opportunity for the emergence of a variety of movements around the country. Researching the revolutionary era and its impact on the national identities of non-Persian national communities (such as the Kurds, Arabs, Turkmen, Baluchis, etc.) through the lens of critical theory shows that this era provided subaltern ${ }^{3}$ groups an opportunity of manifesting their strong opposition to the Pahlavi regime's decades-old policies of exclusion and socio-political deprivation towards their communities. These subaltern national groups raised their demands for some degree of political and cultural autonomy after the collapse of the Pahlavi dynasty (Sharifi, 2013). As one Iranian newspaper put it in 1979, "the revolution woke up the oppressed people of the region" (Tehran Musavvar, 1979e, pp. 30-32).

The Revolution was viewed by non-Persian national communities as an opportunity for mobilising on their grievances and expressing their demands for autonomy. The people of Khuzestan in the southwest, Kurdistan in the west and northwest, and the Turkmen Sahra in the northeast, experienced the Revolution in a fundamentally different way to the dominant Persian community. Their claims of socio-political and cultural autonomy quickly placed the people of these regions in opposition to the Provisional Revolutionary Government in Tehran. ${ }^{4}$ The rapid intensification of political activity among these subaltern communities appeared as a serious challenge to the authority of the ruling elite in Tehran (Elling, 2013, pp. 45-46). The Islamic regime characterised by Ayatollah Khomeini's authoritarian tendencies soon eliminated any space for the political activism of its opponents, and ushered in a post-revolutionary state of terror (Ghamari-Tabrizi, 2016, p. 8).

\footnotetext{
${ }^{1}$ Correspondence author's email: a.hassaniyan@exeter.ac.uk

${ }^{2}$ Sheikh Ezzedin Hosseini was a spiritual leader of the post-revolutionary Kurdish movement, and spokesperson of the Kurdish negotiation team during negotiations with the Provisional Revolutionary Government (Khosravi, Aghapouri, \& Hamehmorad, 2016; Mofidi, 2016, pp. 30-31).

3 The term subaltern has been introduced by the Italian Marxist Antonio Gramsci to identify the social groups excluded and displaced from the socio-economic institutions of society in order to deny their socio-political and cultural voices. The terms subaltern and subaltern studies entered the vocabulary of post-colonialism through the works of South Asian scholars' constituting the so-called Subaltern Studies Group of historians in the late 1970s (see, Beverley, 1999).

4 The Provisional Revolutionary Government/Interim Government of Iran (1979-1980) was the first postrevolutionary government in Iran. This transitionary government was formed by order of Ayatollah Khomeini on 4 February 1979, while Shapour Bakhtiar (the Shah's last Prime Minister) still claimed power (Milani, 1994, p. 143).
} 
With regard to the Kurdish people and their liberation movement, as shown in this article, the Revolution provided the Kurdish movement with great opportunities. In ways unseen since the fall of the Republic of Kurdistan in late $1946,{ }^{5}$ the movement succeeded in mobilising the masses of Kurdish society (Elling, 2013 , p. 45). The Revolution provided the Iranian Kurdish movement with framing structures based on new spatial, political and resource opportunities (Romano, 2006, p. 109). It should nevertheless be mentioned, when arguing that the Revolution provided the Kurdish movement with opportunities based on new circumstances, the significance of the experiences of the previous three decades on Kurdish society should not be underestimated (Faltis, 2014; Khosravi, Aghapouri, \& Hamerhmorad, 2016). One partial explanation for the rapidity of the mobilisation of Iranian Kurdish civil society during the Revolution is that the movement was strongly shaped by conditions inherited from the past. The Kurdish autonomy movement in post-revolutionary Iran did not simply flare up overnight: the socio-political development and the events which took place in the years between the Mahabad Republic and the Revolution left a mark which later appeared in the attitude of the Kurds towards the postrevolutionary government.

The Kurdish Democratic Party of Iran (Partiya Demokratîk a Kurdistana Iranê, KDPI, also known as PDKI), established in Mahabad in 1945 and until today the largest political and military Iranian Kurdish organisation, made several attempts to revive its political and armed struggle in the decades following the collapse of the Republic. Its efforts were thwarted by state repression. The KDPI's Revolutionary Committee of seven members, led by Ismail Sharifzadeh was declared in the summer of 1966 near Alanê, a village of Sardasht (Kaveh, 1996, pp. 151-152). The Revolutionary Committee's attempt to establish a proactive political and armed struggle inside Iranian Kurdistan in the late 1960s was among the most noteworthy political events during this period. During the 1967-1968, areas of Iranian Kurdistan such as Saqqez, Baneh, Sardasht, Bokan and Piranshar were the scene of political activity initiated by Sharifzadeh and his comrades (Kaveh, 1996, pp. 170-173). However, the Revolutionary Committee remained isolated, with little popular support and no safe haven from which to direct its activity. After 18 months, the Committee ceased to function in 1968 after many of its members, including Sharifzadeh, were surrounded and killed by the Iranian Army in a village near Baneh. Other members of the Revolutionary Committee lost their lives in other incidents. Losing its leadership, the Committee vanished totally (Hisami, 1971, p. 91).

Despite the Committee's short life and its failure to establish a proactive movement, it was the most politically significant and influential phenomenon in Iranian Kurdistan during the late 1960s (Moradbeigi, 2004, p. 28). Following the Committee's defeat, politically active Kurdish intellectuals continued to attempt to remobilise the movement through establishing clandestine cells inside Kurdistan. Simultaneously from the 1950s to the early 1970s, a process of the politicisation of national and cultural identity was reshaping Kurdish society. This was demonstrated by the rise of class consciousness, especially among landless peasants, and the sporadic occurrence of peasant uprisings across Kurdistan (Gelawej, 1983; Hassaniyan, 2019a).

\section{Source Material and Theoretical Framework}

Historical reflection on the brief post-revolutionary era in Kurdistan provides insights into the actions and interactions of different groups over a substantial period of time. According to Tilly "historical analysis, taken seriously, will help us fashion more adequate models of power struggles [...] Collective action, contention, and struggles for political power are especially likely to leave their traces in the historian's raw materials" (1978, pp. 231-232).

A combination of primary sources, including archived documents and the personal accounts and narratives of individuals in the Kurdish movement, with secondary sources on the socio-political development in Iran and Iranian Kurdistan through the second half of the twentieth century, have been drawn upon in this study. Specific archives of primary material include the archive of Behzad Khoshhali ${ }^{6}$ and the collection of the Nashriyah newspaper at the University of Manchester. ${ }^{7}$

Theoretically, this paper applies McAdam, Tarrow and Tilly's approach to social movements. The approach of these scholars to movements embraces different social phenomena, such as social movements,

\footnotetext{
5 The Kurdish Republic of 1946 was founded by the Kurdish national leader Qazi Mohammad in the city of Mahabad. The Republic lasted only eleven months. It collapsed as a result of Reza Shah Pahlavi's attack on the Republic, followed by the intensive militarisation of Iranian Kurdistan and mass executions of the Republic's leaders.

${ }^{6}$ The 20 volumes of material on Kurdish society and political parties collected by Behzad Khoshhali are available at https://www.iran-archive.com/start/215

7 The weekly magazine Tehran Musavvar, published in Tehran, reported regularly on the events in Kurdistan. It provides detailed information on the interactions between the Kurds and the central government during this period. The materials are electronically archived and made available by the University of Manchester at https://luna.manchester.ac.uk/luna/servlet/view/search?q=+musavvar\&search=SUBMIT\&QuickSearchA=Quick $\underline{\text { SearchA\&sort=title\%2CmediafileName\%2Cidentifier\&pgs=50\&res=1\&cic=Manchester } \sim 18 \sim 18}$
} 
revolutions, nationalism, and democratisation (James, 2019; McAdam, McCarthy, \& Zald, 1996, p. 4). Based on the structure of the Kurdish movement and the challenge it posed to successive regimes in Iran, the movement can perhaps best be categorised as a nationalist contention that, following the 1979 Revolution, expressed support for the democratisation of Iran as a solution to the Kurdish and other national questions in the country (Entessar, 1992). Tilly's (1978) theoretical approach to collective action, identified as 'dynamic statism', focuses on how changing conditions (re)produce political opportunities for collective actions. This approach "allows us to specify political opportunity for different actors and sectors, to track its changes over time, and to place the analysis of social movements in their increasingly transnational setting" (McAdam et al., 1996, pp. 45-46). According to McAdam et al.; social movements and revolutions are shaped by the broader set of political constraints and opportunities unique to the national context in which they are embedded (1996, pp. 2-3). Any environmental factors that facilitate movement activity can be conceptualized as political opportunities (Bhat, 2019; Tolba, 2018). In addition, theories of non-violence and civil resistance can be applied to the collective actions of Kurdish civil society in the post-revolutionary period. As defined by Roberts, civil resistance is "the power of people", with which civil society movements across the globe have shaped world politics using non-violent methods of protest, persuasion and non-cooperation (2009, pp. 1-20). Roberts defines civil resistance as a type of political action that relies on the use of non-violent methods, and involves a range of widespread and sustained activities that challenge a particular power, force, policy, or regime-hence the term 'resistance.' The adjective 'civil' in this context denotes that which pertains to a citizen or society, implying that a movement's goals are civil in the sense of being widely shared in a society; and it denotes that the action concerned is non-military or non-violent in character (2009, p. 2).

This article reflects on the conflictual interactions between the Kurds and Tehran during the short postrevolutionary era, and sheds light on several of the major actions of Kurdish civil society, conducted to peacefully claim political and cultural autonomy and resist the new government's attempt at establishing authoritarian rule. This article argues that the continuing Kurdish question in Iran is mainly a product of the post-revolutionary era's conflict between the Kurds and Tehran. While Kurdish society and its movement attempted through non-violent collective actions to resist the centralisation of power and consolidation of authoritarian rule, the government repeatedly resorted to the use of force when facing Kurdish resistance.

\section{Post-Revolutionary Iranian Kurdish Politics}

A major opportunity provided to the Kurdish movement by the Revolution was the end of three decades of exile-based nationalism. Exile outside Iranian Kurdistan had been imposed on the movement as result of Mohammad Reza Shah Pahlavi's zero-tolerance attitude to Kurdish political and cultural activism after the collapse of the Republic of Kurdistan. With the return of the leaders and members of the KDPI in the months prior to the Revolution, and a new phase of the KDPI's movement mobilisation in close interaction with civil society, three decades of exile ended (Hassaniyan, 2019b; Vali, 2016). The first major event following the return of the KDPI's leadership from exile was the Great Meeting in Mahabad held on 1 March 1979. During this meeting, the KDPI's leader Abdulrahman Ghassemlou announced the official activity of KDPI after decades of clandestine and exile-based activity. In the presence of Iranian and international journalists, he emphasised that "freedom and democracy in Iran, without providing freedom and democracy to the Kurdish people, will not be gained. On the other hand, the Kurdish struggle will not gain any achievements, without freedom in Iran" (Ettelaat 3 March, 1979, see, Khoshhali, 2008a, p. 3; Mohséni, 2018, p. 225). In addition, following the announcement of the official activity of the Society of Revolutionary Toilers of Iranian Kurdistan (Komełey Şorş̧ếrî Zêhmetkêşanı̂ Kurdistanî Éran, known as Komala) on February $15,1979,{ }^{8}$ the Iranian Kurdish movement experienced the first major diversification among its actors and organisations. Komala approached Kurdish politics and society quite differently from the KDPI, which had hitherto been the only Kurdish political party in Iran (Mofidi, 2016, pp. 3031).

In addition to the influence of the heritage of the movement, the evolution of the Iranian Kurdish movement in this period was shaped by a variety of events and incidents. The post-revolutionary Kurdish movement redefined itself with the adoption of non-violent collective resistance and civil disobedience campaigns, involving different sections of Kurdish society. These actions aimed at both challenging the new regime's attempts at enforcing its authority, and convincing the regime to recognise the elected city councils (şoray şar) which had been formed in different Kurdish cities. Establishing the şora (council) was the first step towards creating an alternative democratic system of government through empowering the local representatives of the Kurdish people to manage the affairs of their cities and neighbourhoods (Golperiyan, 2014, p. 25). The high level of cooperation between different members, with different ideologies, ensured the councils status as a unique model of municipality (Ardelan, 2015).

\footnotetext{
${ }^{8}$ The history of Komala's formation is contested. According to personal narratives, before the Revolution, Komala was as an informal group referred to as "the Organisation" (Teshkilat), formed by a group of Kurdish intellectuals and students studying at universities in Tehran and Tabriz from 1968 to 1969. (Mofid, 2016, p. 30).
} 
The rapid transformation of the Kurdish struggle into a proactive and mass movement was partly a product of the Iranian state's weakness at the end of the Shah's rule and the beginning of the Revolution (see Keddie, 2003, pp. 249-256), enabling the Kurds with an opportunity to express their grievances and demands in a highly politicised manner. The return of the KDPI and the arrival of Komala on the stage, also played an important role in remobilising the Kurdish movement. Throughout this era, Kurdish society became intensively politicised, and the movement enjoyed its members' strong loyalty. The Kurdish people's involvement in non-violent resistance activities demonstrated consensus, cooperative interaction, political orientation, and loyalty to the Kurdish movement. Writing of the Kurds' participation in the Revolution, Entessar notes that "the Kurds of Iran have certainly been an integral part of this struggle, and they have largely framed their demands for recognition of their socio-political and cultural rights within the broader context of a democratic and decentralized Iran" (2014, p. 211).

However, the relations between the Kurdish movement and the regime after the Revolution were complex, and have resulted in four decades of conflict. By repeating the oppressive policies of the Pahlavis, the Islamic government's approach to the national questions in Iran has furthered grievances and disillusionment among Iran's non-Persian and non-Shi'ite national and religious communities (Elling, 2013). Raising the claim of autonomy (khodmokhtari), the Kurdish movement met with a harsh reaction from Khomeini and his circle, to the extent that the movement was labelled a counterrevolutionary conspiracy, sponsored by foreign powers (Shams, 2006, pp.158-160). Just one month after the fall of the Shah, due to the new regime's military approach, Kurdistan had become a warzone. Photographs accompanying newspaper reports from Kurdistan show images of barricades, machine guns, ambulances and wounded and lifeless bodies. It was the national army (Artesh) which perpetrated many of the shootings. As noted in Tehran Musavvar, "thousands of mortars, sonic bombs and smashed windows were the new year's gift (Newrozane) of the Iranian army to the Kurdish people" (1979b, pp. 12-13).

\section{Revolution in Iran, War in Kurdistan}

Throughout the four decades of the Islamic regime in Iran, the Kurdish demand of autonomy and its supposed threat to Iran's territorial integrity, and the secular ideology of the Kurdish movement, have led the Kurds to clash with the government. Articulating the Kurdish movement as primarily a defensive movement necessitates the recognition that armed insurgency has been imposed on Kurds, who were left with no other options by the government's attitude. This in turn has been reflected in the Kurdish leadership's articulation of their demands, and in the actions of the Kurdish movement. As Sheikh Ezzedin Hosseini stated,

The war in Kurdistan was initiated by the government, and while it attacked us, what we did was a matter of self-defence. A people who make a claim [for selfdetermination] and are a minority will never be interested in war, because they know that their counterpart is [militarily] stronger than them, that's what we Kurds did and considered (BBC Hardtalk, 2015).

The Revolution resulted in two major developments for Kurds: firstly the start of a new era of the Kurdish movement; and secondly, the transformation of Kurdistan into a battleground between the Kurds and the government, where victory became a crucial goal with ramifications on the new regime's capability to consolidate its power. Iranian Kurds viewed regime change as an unrivalled opportunity for coming a step closer to their dream of self-determination. As highlighted by Entessar, "after years of suppression by the Shah's regime, it was natural that the Kurds would enthusiastically support the Iranian Revolution of 1978-1979. In fact, a broad spectrum of the Kurdish population participated in the revolutionary process from the outset" (2009, pp. 34-35). With such an approach to regime change, during and after the Revolution the Kurds mobilised their acts of self-governance. Actors from Kurdish civil society, grassroots organisations and political parties, by electing members to şoray şar, initiated the first act of political self-rule. The establishment of grassroots organizations and unions, such as the Union of the Unemployed in Baneh, the Union of Teachers in Mariwan, the Union of Bakers in Saqqez, and the Centre for Reviving Kurdish Culture (Benkay Bojanewe Ferhengi Kurd) in Saqqez (Khoshpeyam, 2019; Mostafa Sultani \& Watandust, 2015), showed civilians' commitment to change in post-revolutionary Kurdistan through peaceful, community-based solutions. These developments were products of the new circumstances following regime change. The emergence of new windows of opportunity, combined with the increasing politicisation of Kurdish society, lent the Revolution in Kurdistan its particular characteristics. During the Revolution, various civil society organizations were established. The Democratic Organizations of Kurdistan (an umbrella organization), the Women's Committee of Mariwan, the Union of Students, the Union of Unemployed Labourers, and the Society of Militant Women of Saqqez are other examples of the established unions and organizations working collaboratively in solving different issues in Kurdish society (Moradbeigi, 2004, pp. 210-238). For example, the objective of the Militant Women of Saqqez was the elimination of gender inequality and the exploitation of women by men: 'this organisation has endeavoured to provide what it has termed as 'gender-specific' benefits to Kurdish 
women. These include improving welfare benefits and working conditions of working Kurdish women" (Entessar, 1984, p. 931).

The acts of Kurdish civil society caught the attention of the Iranian intellectual Shokrollah Paknejad to such a degree that he stated that "I feel that the heart of the Iranian Revolution is beating in Kurdistan, because Kurdistan has become the stronghold and port of democracy in Iran” (see, Mostafa Sultani, 2006, p. 241). Kurdistan took the lead in large-scale collective non-violent actions. One example was the evacuation of the city of Mariwan, which became known as the Historic Exodus of Mariwan (Koçi Mêjûŷ̂ Mariwan), discussed below. Kurds framed their demands for Kurdistan within a new Iranian political system around the concept of khodmokhtari (autonomy) for Kurdistan, and democracy and secularism for Iran. As emphasized by Sheikh Ezzedin Hosseini, "through this era we need a government that is capable of listening to the people. If the new regime disregards this need, a new system of khefeqan (suffocation) will dominate the country" (Tehran Musavvar, 1979c, p.31).

The non-violent movement of Kurdish civil society faced an uncompromising response from the new regime. While the Islamic government shortly after its establishment succeeded in establishing its control across most of the country, Kurdistan was an exception (Kreyenbroek \& Sperl, 2010, p. 150). There, the regime struggled to enforce its authority; controlling the situation in Kurdistan became a strategic and symbolic task, with repercussions for the regime's authority in other parts of Iran. The fear that "Kurdistan would turn into a source of inspiration and a safe haven for other opposition groups" (Saheb, 2017) encouraged the regime in acting immediately and aggressively. In the weeks and months following the Revolution, Kurdistan was rocked by events the like of which were unseen in other parts of the country.

While following the Revolution Khomeini became a figurehead for many of the Iranian revolutionary groups in Tehran, such support was absent in Kurdistan, and despite Khomeini's uplifting promises (Abrahamian, 1993, p. 32), his populist discourse did not win the Kurds' support. Khomeini's ambition was the creation of a new political system which was incompatible with the demands raised by the Kurds. Sheikh Ezzedin Hosseini, reacting to the authoritarian approach of Khomeini, stated "mardoom qayom nemikhahed, the people do not need a guardian" (Khoshhali, 2008c, p. 31). From the beginning of the revolutionary process, there was little overlap between the Kurds' reasons for participation in the Revolution, and the aims of Khomeini and his supporters. In the words of Seyedi (2018), "Kurds did join the Revolution but did not support an Islamic alternative to the monarchy. For Kurds, the national and class issues were the main motivations for joining the Revolution".

The conflictual relations between the Kurdish movement and the Islamic regime resulted in many incidents of bloodshed across Kurdistan (Tehran Musavvar, 1979a, p. 16). Through the chaotic post-revolutionary days, ethnic and sectarian clashes and massacres took place in Kurdistan's cities. In Neqhade and Urmia, which have a mixed ethnic demographic composition of Kurds and Azeris, fundamentalist groups of Azeris under the leadership of Mulla Hassani (a conservative Azeri cleric), in cooperation with the Iranian army, conducted massacres against Kurdish civilians (Khoshhali, 2008f, p. 6; Mohséni, 2018, pp. 217-232).

Kurdistan also became subject to heavy attack from the regular army. The Iranian army, which had been the primary force opposing the masses and revolutionary groups before and during the Revolution, turned overnight into an effective force of the Islamic government in attacking the Kurdish people. The army's participation in the massacres of Naqhadeh, Paweh, Qarne and Qelatan demonstrated its destructive role in Kurdistan. Incidents such as the Bloody Newroz of Sanandaj (Newroz-i Xwenawi Sna) of 18-30 March 1979, and the Three-Month Battle (şeri sê mange) of August-December 1979 (Moradbeigi, 2004, p. 143) would define relations between the Kurds and the government over the succeeding decades. Khomeini was determined to deal harshly with all who opposed him; from the moment of his arrival in Iran in February 1979, he ordered the army to turn the country into a 'graveyard' for his opponents (Nikraftar, 2017, p. 11).

\section{The Regime's Media Hostility and Anti-Kurdish Propaganda}

The public Radio-TV were among the most provocative institutions of the state in this period. This issue was highlighted by Tehran Musavvar, which asserted that "the public Radio-TV plays a destructive role, distorting the truth of the events in Kurdistan" (1979e, p. 22). The Radio-TV worked as a propaganda machine that provoked the Kurds, to the extent that the Kurdish people several times during this period protested and condemned the antiKurdish role of these channels. The state-controlled media spread false information, aimed at labelling the Kurdish movement as anti-revolutionary and an instrument of the West in Iran. For instance, they spread false stories alleging that "the Kurdish Peshmerga are kidnapping women and girls", "the KDPI and Komala have shut down all mosques in Kurdistan and people are not allowed to pray", "Israel helps Iranian Kurds by giving them weapons", and that "5000 Kurds from Turkey have crossed the border to support Iranian Kurds" (Khoshhali, 2008e, pp. 65-67). The şora of different cities of Kurdistan, as protest against the Radio-TV's anti-Kurdish agenda, invited the Kurdish society to take part in mass strikes. During the Kurdish-regime disputes, Kurds living in Tehran, similarly to the Kurds resident in Kurdistan, made a positive contribution to the Kurdish movement, for example they facilitated the negotiations between the Kurdish leadership and the government. The Centre of Iranian Lawyers in Tehran played a prominent role in supporting the Kurds. The 26 points (document of autonomy) 
was formulated by prominent Kurdish intellectuals and lawyers as Aziz Mamle, Ali Hassaniyan, and Sarmedin Sadegh Waziri (Aliyar, 2019), which all three were resident in Tehran. For instance Behroz Sulaimani a Kurd living in Tehran, approached the Minister of Interior during a meeting, stating that "the Kurdish people have been attacked on the basis on false accusations. They [Kurds] have become a direct target of regime hostility" (see, Khoshhali, 2008g, pp. 1-2).

Ghamari-Tabrizi notes that the violent approach of the regime to any opposition has been due to the fact that "Khomeini knew that the unity and uniformity afforded to his leadership by the revolutionary movement, would not remain uncontested for long after the triumph of the Revolution" (2016, p. 121).

This phase of the movement evolved under the influence of a chain of political incidents (Thomasson, 2012, pp.702-703) resulting from the dispute between the Kurds and the Islamic government. As noted by Thomasson, "some 'big events, but also the many small acts that people [...] carry out to improve their situation' are the formative elements that manage to bring about change through sensitive moments of revolution" (2012, p. 682). Particular events, such as the Bloody Newroz of Sanandaj and the Historic Exodus of Mariwan, and their impacts on Kurdish society, cast a long shadow over the following decades of relations between the Kurdish movement and the central government. The Revolution, despite initially being seen as a window of opportunity, ultimately resulted in disillusionment and new waves of institutional authoritarianism. This development led many in the Kurdish movement to ask questions concerning the blame for the violence in Kurdistan, and the reasons behind events such as the Bloody Newroz (Tehran Musavvar, 1979a, p. 13).

\section{Sanandaj: The Epicentre of Contention}

Sanandaj, known to the Kurds as Sna, was the first city to be targeted by the Iranian army after the Revolution, attracting the government's attention with its strategic location and its symbolic status as the capital city of Kurdistan province. The Bloody Newroz took place less than five weeks after the Revolution, and several days before the celebrations of the Iranian and Kurdish New Year (Newroz) on 18 March 1979. The army's attack resulted in over 220 civilian deaths and injuries (Nesrollabaegi, 2011). The event was a signal sent to the Kurdish movement by the government, that the national army and the Islamic Revolutionary Guard Corps (Sepah, IRGC) were the only forces to be tolerated in Iran, highlighting the government's willingness to deploy violent means in defeating its opponents (Tehran Musavvar, 1979a, p. 18).

In the eyes of the regime, the Kurds' creation of the city councils, and raising the demand of autonomy, were serious obstacles to the Islamic government's intention of creating a strong centralist theocratic political regime. As emphasized by conservative elements of the regime, such as Chamran, Bani Sadr and Rafsanjani, the revolutionary government would not tolerate such a situation; Kurdistan would not be treated differently from any other part of Iran (Seyedi, 2018). The Kurdish Sunni cleric Ahmad Moftizadeh, the founder of the Maktab Quran movement (a Quranic school in Iranian Kurdistan), ${ }^{9}$ and the Shi'ite cleric Ali Safdari, ${ }^{10}$ Khomeini's representative in Kurdistan, led groups that created a short-lived alliance that in line with the rapid development in Kurdistan disputes related to access to military resources and Sanandaj's Radio-TV, interrupted this alignment, and resulted in conflict between them too. The emergence of such relation furthered the uncertainty of the already fragile situation in Kurdistan (Mohséni, 2018, p. 225; Moradbeigi, 2004, pp. 84-85). The relationship between these groups, the city councils' protests against the army's presence in Sanandaj, and opposition to the actions of the Islamic regime's Revolutionary Committee (an ideological armed faction of the regime) in Sanandaj, are assumed to be the main factors behind the worsening of the situation in Sanandaj, which led to the events later known in the lexicon of the Kurdish movement as the Bloody Newroz.

As a reaction to the regime's attack, the people of Sanandaj, organized a thirteen-day long collective hunger strike or 'political fasting' (roze-ye siyasi, January 1980), a tactic which was also used in other parts of Kurdistan. This action was a combination of protest and condemnation, and aimed at forcing the exit of the Pasdaran and the Iranian army from Sanandaj by peaceful means. Awad referring to strikes as an essential element of non-violent resistance claims that "strikes are a form of refusal to cooperate", used by Palestinians against Israeli defines in the West Bank and Gaza (1984, p. 32). In the words of one of the protesters in Sanandaj (January 1980), "we are not members of any political parties, our hunger strike aims at forcing the Pasdaran out of the city. This force has, behind the mask of establishing order, come to the city to quell the voice of the people" (see, Khoshhali, 2008e, pp. 212).

Seyedi (2018) holds that "the Islamic regime viewed the Kurdish movement as a dichotomized element that had to be defeated before the planned referendum for the Islamic Republic on 30 March 1979". The Kurdish movement's resilience in not giving up its demand of autonomy, and its high degree of politicisation and capability

\footnotetext{
${ }^{9}$ The Maktab Quran or School of Quran is the oldest Sunni Islamist religious/ideological organisation in Iranian Kurdistan. Political Islam was introduced to the region in the 1960s by Ahmad Moftizadeh (Khosravi, et al, 2016, p. 59).

${ }^{10}$ According to Mohséni, Ali Safdari, a Shi'ite cleric, "was sent by the government to take control of the [Sanandaj] city garrison and armed forces" (2018, p. 225).
} 
in mobilising a whole society, located Kurds in the position of a significant challenger of the regime. The patterns of development in Iran show that enforcing authority through creating chaos was a calculated method deployed by the regime. The chief aim of the regime's use of military force was to bring an end to the dichotomy of the power situation in Kurdistan, and enforcing its authority in this region before the referendum on the Islamic Republic. For instance, Mostafa Chamran (the first defense minister of post-revolutionary Iran) approached the Kurdish issue from a military angle, repeatedly justifying and advocating the deployment of the army as the only effective solution guarantying regime's authority in the Kurdish region (Mostafa Sultani, 2006, pp. 374).

Nevertheless, in line with the escalation of the crisis in Kurdistan and the Kurdish movement's resilience, gaining the Kurdish movement's support for the referendum pushed the regime into a position of accepting temporary compromise. A series of negotiations between Kurds and representatives of the Provisional Revolutionary Government (the so-called goodwill delegation) took place (Tehran Musavvar, 1979d, pp. 44-46). However, this was without positive outcome for the Kurdish movement. In this period, Kurdistan experienced a complex condition of 'no war yet no peace'. Subsequently, the government intensified rapidly large military campaigns against Kurdistan.

In order to stem the tide of armed conflict in Kurdistan, Sheikh Mohammad Sadeghi Guivi (Sadegh Khalkhali, a hardcore clergyman) was dispatched to the region to 'crack the whip' on the Kurdish people and take revenge on the Kurdish movement, for their opposition to the referendum of the Islamic republic. Khalkhali, similarly to other hardline elites of the regime, believed that deploying military force, and the mass execution of opponents, were the only solution for the conflict in Kurdistan. The brutality of Khalkhali meant he became known as the butcher of Kurdistan (Qesab-e Kurdistan). Through a series of mass executions, Khalkhali executed hundreds of Kurdish civilians and political activists (Amanat, 2017, pp.779-781; Mahbobi, 2017). Kurdistan during this era experienced a comprehensive reign of state terrorism. The Islamic government's arbitrary mass executions were widespread acts of punishment of the Kurdish society for their claim of Khodmokhtari and boycotting the referendum on the Islamic Republic. The mass executions of eleven Kurds (among them injured prisoners) in Sanandaj's airport on 27 August 1979 (IHRDC, 2011), the 47 Kurdish men and women on 2 September 1979 in Sanandaj, 59 youth on 2 June 1983 in Mahabad, which order was signed by Hamidreza Jalaipour, Governor of Mahabad (Khoshhali, 2008e, p. 154), and many hundreds in Saqqez (among them, the two sisters; Shehla and Nasrin Kabi, both nurses, were among the civilians executed without trial), are among the examples of the regime's brutal treatment of civilians in Kurdistan. The first wave of Khalkhali's execution of the Kurds took place in August 1979 after Khomeini's decree (Jihad) to attack Kurdistan, issued on 19 August 1979, triggering the comprehensive military invasion at Paweh. As an element of terrorisation of Kurds, Khalkhali sent many doctors, nurses and other employees of the health and education system to exile in other parts of Iran. Reacting to such brutality, Moftizadeh in an open letter stated:

Dear countrymen and the Islamic Umma [nation] of Iran, what your Kurdish brothers and sisters following the defeat of the Shah have experienced is very different to what you read in the newspapers. While the rest of Iran was busy celebrating the victory against the Shah, just a few days after this victory, the remaining elements of the regime on the pretext of 'Revolution and order', committed a massive attack against the Kurdish people. Yet the Kurdish people disappointedly wonder why their fellow countrymen are quiet while these criminals destroy Kurdistan (see, Khoshhali, 2008d, pp. 42-43).

\section{Announcing the city councils (şoray şar)}

The people of Sanandaj insisted on enforcing the şora system; yet, from the government's perspective, the şora model was a parallel power institution challenging its authority. Ardelan (2015), a member of Sanandaj's city council, describes the şora as a bottom-up project, started as a neighbourhood initiative in Sanandaj in October 1978. Other cities of Kurdistan found it inspiring, and implemented the system in their areas. As the Revolution in Kurdistan was primarily mobilised by leftist, nationalist and secular forces, following the Revolution these groups had the shared responsibility for mobilising the masses in Kurdistan, and adherents of these ideologies were identifiable in the şora establishment (Mostafa Sultani \& Watandust, 2015, p. 23). Ayatollah Mahmud Taleqhani (an Iranian theologian, Muslim reformer and a senior Shi'ite cleric) after his visit to Kurdistan and inspired by the degree of integrity of the şora of Sanandaj, proposed implementing this idea of municipality in the rest of Iran. However, according to the autobiography of Taleqani, "under the impact of conservative forces in Tehran, certain Islamic forces in Sanandaj declared that they did not support the current şora, and they demanded a fully Islamic şora" (Seyedi, 2018). However, Bani Sadr and Rafsanjani (both members of the Goodwill negotiation team and close to Khomeini) disagreed with Taleqani's proposal, questioning the şora and its function as an initiative undermining the government's authority.

These şora had, with the direct participation of the locals, contributed to neighbourhood security, managed market prices and distributed essential household goods such as petrol and flour to the people. This model 
of municipality functioned in Kurdistan for nearly six months, until the withdrawal of the Peshmerga from Kurdish cities. Kolaqochi (2015) points to the Kurdish civil society's resilience in enforcing the şora system as a unique form of resistance and a causational factor behind the escalation of the Kurdish-government tension. Enforcing the rule of the şora was an important part of the demands of democratization in Kurdistan. As part of the Kurdish plan of khodmokhtari, Kurds demanded that "all security institutions in Kurdistan should be run under the supervision of a joint military committee of patriotic officers and representatives of the Revolutionary Council, and the army's garrisons should be moved out of the cities" (Mohajer, 2014). Since such demands were considered by the government as part of a Kurdish attempt at excluding regime authority, the government never accepted to deal with the Kurdish claim through peaceful means (Kolaqochi, 2015).

\section{The Meeting of Naqhadeh and Ethnic Clashes}

In the attempt at enforcing authority in Kurdistan, a combination of creating chaos and deploying the policy of divide and rule were systematically adopted by the government (Nikraftar, 2017, p. 32). The Kurdish leadership on several occasions warned the regime against this policy; for instance, Sheikh Ezzedin Hosseini, in a letter to Bazergan (first PM after the Revolution), emphasized that "the biggest mistake of the government is that it will spread the seeds of division among Kurds" (Tehran Musavvar, 1979b, p. 22).

The government sponsored sectarianism systematically to weaken the Kurdish position. For instance, the government and its army by support for distinct groups within the Azeri community on several occasions, and in different parts of the Kurdish region, employed the sectarian card (Mohséni, 2018, p. 226). The occurrence of immense tension in Naqhdeh and Urmia and the massacres in Qarne in 2 September 1979 (where 47 civilians were killed) are examples of massacres sponsored by the Iranian army. On 20 April 1979, during a political meeting organized by the KDPI, the city of Naqhadeh (an ethnically Kurdish and Azeri city) witnessed a catastrophic occurrence, with a massive loss of life, leading effectively to the displacement of much of the city's Kurdish population. The leadership of the Kurdish movement accused the Iranian army of having a share in attacking the Kurds in Naqhadeh and neighbouring areas. As the KDPI leader, Ghassemlou stated in a visit to Tehran.

We know some forces are trying through their provocative acts to create tension between us and the government. In this regard we are here to warn the authorities and to overcome misunderstanding related to these issues. However, our experience is that the government is not paying attention to these matters, or maybe deliberately ignores these issues in Kurdistan (see, Khoshhali, 2008a, pp. 19-20).

\section{Mariwan's Historical Exodus (Koçi Mêjûŷi Mariwan)}

In line with the intensification of the Kurdish-government tensions, the means of resistance adopted within the Kurdish movement diversified. The flourishing Kurdish civil society's multifaceted activities became a real challenge to the government's enforcement of authority in Kurdistan. An example of the politicised civil society activity was the mobilisation of collective welcomes for released political prisoners in Kurdistan. For instance, in Mariwan, "celebrating political prisoners' release, and holding welcoming speeches for them, was a method used and promoted by Foad Mostafa Sultani, as an effective means of mobilising people" (Mostafa Sultani, 2006, p. 181).

Awad - which study concerns Palestinian non-violent resistance against Israel defines - claims that "school and commercial strikes, petitions, protest telegrams, advertisements and condemnations in the daily papers, and the attempts to boycott Israeli goods are, in fact, manifestations of non-violent struggle" (1984, p. 22). The Kurdish civil society relied largely on peaceful collective actions such as strikes, hunger strikes, solidarity rallies, and shutting down bazars, school and offices as means of collective resistance. The activities of Kurdish civil society were framed around protest actions against the acts and policies of the newly established Iranian government (Khoshhali, 2008b, p. 57). The rally of the people of Sanandaj for releasing eight members of Komala imprisoned in Mariwan (Mostafa Sultani \& Watandust, 2015, p. 140), the shutdown of the bazars for weeks seeking the expulsion of the Pasdaran from Kurdish cities, and the hunger strikes of the people of Baneh and Paweh are among the incidents of non-violent civilian disobedience activities of the Kurdish society taken place during the post-revolutionary period (Mostafa Sultani \& Watandust, 2015, p. 26).

Along with many other Kurdish cities, Mariwan was the scene of many events. The people of this city took an active part in the Revolution, turning Mariwan into a centre of activity of different political groups. Koçi Mêjûŷ̀ Mariwan was one of this era's most notable events in Kurdistan, an act of resistance leaving a mark on the identity of this city, revealing the Kurdish persistence in claiming their demands through peaceful collective actions. The exodus of Mariwan's residents was a decision made by şoray Mariwan, and received massive support and solidarity from the major part of Iranian Kurdistan (Mostafa Sultani, 2006, pp. 374-376). The exodus lasted in 14 days (23 July-5 August 1979). Foad Mostafa Sultani played a crucial role in different incidents in Mariwan, and in mobilising the exodus. During a protest action before the exodus, the pasdaran opened fire at protesters 
gathered in the front of the Maktab Quran in Mariwan, in 14 July 1979. The people of Mariwan protested, against the Radio -TV and Sepah's policy in the city. Through this protest demonstration three of those demonstrators were killed, and many other were wounded (Mostafa Sultani, 2006, pp. 364-364). ${ }^{11}$ Similar violent acts of the pasdaran meant that the people of Mariwan mobilised their dissatisfaction and demanded the expulsion of the pasdaran and other military forces from their city. The people of Mariwan repeatedly highlighted that "we have no desire to fight with the government, yet we are not going to surrender to the pasdaran, and the security of our city should be handed to trusted local people" (Khoshhali, 2008h, pp. 92-93).

During a meeting between Chamran and representatives of the people of Mariwan, Chamran threatened the people that unless they gave up their claims, they would face punishment. Chamran stated that the Iranian army was "here for fighting, not celebrating" (Mostafa Sultani, 2006, p. 374). Foad Mostafa Sultani responded that "if you want to attack Mariwan we will leave the city, so come and occupy an empty city" (Khoshhali, 2008h, pp. 9293). With the escalation of the conflict in Mariwan, the regime's hard-line conservative officials such as Chamran approached the Kurdish issue from an absolutely military angle. Chamran advocated the use of military force as the only means guaranteeing the enforcement of the regime's authority in Kurdistan. Chamran's brutal approach was even criticized by the regime's own officials. For instance, Mehdi Bahadoryan, Khomeini's representative for investigating the situation in Kurdistan, stressed in a report that "evidence shows that the feudal class and landlords of Kurdistan, in a 'mysterious plot' led by individuals as Doctor Chamran and General Zahirinezhad, were armed heavily, to suppress the deprived people of Kurdistan” (see, Amjadi, 2011).

One aspect of the Kurdish dissatisfaction with the regime's policy became manifested in the mass exodus. The pasdaran's establishment of bases in Mariwan and their violent behaviour, the destructive role of the Kurdish feudal class and the KDP-Provisional Leadership, and consequently the people of Mariwan's reaction to these issues, all together led to the exodus (Mostafa Sultani, 2006, p. 105). The city council in Mariwan, which policy reflected the majority of the political spectrum in this city, was the main organiser of this exodus. The Peasants' Union of Mariwan (Yekyeti Jotyarani Mariwan) and the Peshmerga forces of this union (established on 29 May 1979) played a significant role before and throughout the exodus. This Union and its small armed force provided educational training, and underpinned the peasants' mobilisation against the landlords in the land areas of Mariwan. The Peasants Union contributed to elevating the confidence of Mariwan's civil society (Mostafa Sultani, 2006, pp. 22-26).

Following an announcement made by Mariwan's city council, the exodus started on $22^{\text {nd }}$ July 1979 and lasted fourteen days. (Mostafa Sultani, 2006, p. 374). The exodus was a turning point in this era's political development in Mariwan. It was simultaneously a peaceful collective protest, an act of civilian disobedience, and a strategy for avoiding a potential massacre of the civilians in this city by the Iranian army and IRGC. During this exodus, roughly half of Mariwan's population (between seven and eight thousand people out of fifteen thousand) left the city, and set up tents in (Camp) Kanimaran, an area outside Mariwan. A large part of the remaining population went to stay with families and relatives in neighbouring villages. People of different parts of Kurdistan initiated actions such as providing the Camp Kanimaran with food and other essential supplies, and rallies lent their collective solidarity to the exodus. As an element of solidarity, in many cities of Kurdistan, such as Sanandaj, Kamyaran, Saqqez, Baneh and Bokan, people walked toward Mariwan, and arrived to the Camp Kanimaran after several days (Mostafa Sultani \& Watandust, 2015, p. 405).

The mass exodus was covered by some national media platforms. For instance, Tehran Musavvar made special reports on the exodus and different aspects of life in Camp Kanimaran (1979g, pp. 27-37). Reflecting on the multiple (political and symbolic) aspects of this exodus reveals that the Kurdish society of this era have through practicing a wide variety of collective civil resistance expressed high level of politicisation of the society. In addition, this exodus and similar steps of the Kurdish people in the cities and towns of Kurdistan revealed that Kurdistan had developed a strong potential of mobilising its demands through the acts of civil society and conduct of peaceful collective actions. Mariwan's exodus became a source of inspiration for other cities of Kurdistan. Foad Mostafa Sultani in a speech to the masses in Camp Kanimaran stressed that "the exodus has unified the people, and Mariwan has become the stronghold of liberation and we will make the whole of Iran as Mariwan" (see, Mostafa Sultani \& Wantandust, 2015, p. 379). This action challenged many of the unpopular forces like the pasdaran, the army, advocates of Moftizade's Maktab Quran, and the landlords. The şora, which before the exodus was declared illegal by the regime, was officially recognized after the event. Even though the regime never kept its promises, as part of the negotiations following the exodus, the regime promised to remove all its military bases from the city, and hand the security of Mariwan to the police and local forces (Mostafa Sultani, 2006, pp. 374-389).

\section{Conclusion}

\footnotetext{
${ }^{11}$ Raof Koneposhi (teacher), Mohammad Darsid (worker, political activist and member of Union of Unemployed Workers of Mariwan), and Mahmud Baleki (Peshmerga of Yekyeti Jotyarani Mariwan), are the name of the three protesters killed by the Sepah in 14 July 1979 protest action in Mariwan (Mostafa Sultani, 2006, pp. 363-364).
} 
Whilst the Revolution resulted in the change of regime, the establishment of a new model of state-people relations did not result in democratization or socio-political improvement in Iran. The Islamic Republic's terrorisation of its opponents resulted in new disappointment and further deprivation, among the Iranian's. In the case of the Kurdish movement, the current four-decade long Kurdish conflict with the Islamic regime is a product of this disappointment and deprivation. The 1979 Revolution resulted in the re-emergence and reshaping of the structure of Kurdish movement, and massive diversification of the number of actors and ideologies participating in this movement. These new emergences provided opportunities as well as challenges. The sudden rise of the multi-faceted civil society organisations and their activities in Kurdistan reveals that the Revolution did not only provide the Kurdish movement with the opportunity of the re-emergence of the national struggle, but also that Kurdistan possessed a generation of intellectuals, who with the Revolution gained the opportunity to become active and put in practice their potential.

Another account of the Kurdish-central government's interaction in Iran during the post-revolutionary era is that the leadership of the Kurdish movement claim that they practiced maximum flexibility in finding a peaceful solution for the Kurdish question in Iran, while the government and its elites showed nothing than rigidity and denial of the present of a Kurdish claim representing the broader section of the Kurdish society in Iran. For instance, the Kurdish leadership (e.g., Ghassemlou and Sheikh Ezzedin Hosseini) repeatedly expressed their loyalty to the territorial integrity of the Iranian state, and several times reconceptualised and adjusted their demand of autonomy and compromised on its content. As time passed, the Kurdish demand shrank from Khodmokhtari (political, economic and cultural autonomy) to khodgerdani, the lowest level of regional self-rule. In addition, both Ghassemlou and Sheikh Ezzedin Hosseini on several occasions rejected any attempt of separatism. Puts in the words of Ghassemlou "what the Kurdish people want is the provision and guarantee of their national rights in Iran, and not a separate Kurdistan" (Khoshhali, 2008a, p. 2). Nevertheless, the Kurdish expressions of their loyalty seemed to be vain, since the regime in Tehran was very determined in its destructive and anti-Kurdish campaign.

The emergence of ethnic clashes between the Kurds and Azaries is one of the challenges that the Kurdish movement and the Kurdish society after four decades of these clashes, still are reflecting on. These clashes have also resulted in the Kurds consider how in the case of occurrence of any changes in Iran and the Kurdish region avoid emergence of similar conflicts between themselves and the Azari peoples living among, or side by side them.

Arguably, the non-violence collective actions of Iranian Kurds can be suggested to be actions taken place inspired by a global trend dominating many societies and countries during the 1970s-1980s. For instance Randle's study of non-violent action and civil resistance suggest that in this period different forms of actions defined as civil resistance have been deployed against dictatorship in countries of Latin America, Iran, the Philippines, etc. Puts in the words of Randle "the most dramatic examples of civil resistance bringing about the revolutionary overthrow of authoritarian regimes were in Iran in 1979 and the Philippines in 1986" (1994, p. 89). Studying the Iranian revolution from a regional perspective reveals that this revolution had also provided the Iraqi Kurdish political parties with some degrees of opportunity for the re-organisation of their struggle against the Iraqi government. As result of the Algiers Agreement and the Iranian government's withdrawal of its support to the Barzani-led Kurdish movement in Iraq in 1975, this movement dismantled utterly (Phillips, 2019, pp. 38-39). However, the two major parties of Iraqi Kurds, the Kurdistan Democratic Party (KDP) and Patriotic Union of Kurdistan (PUK), viewed the Revolution and regime change in Iran as a golden opportunity for (re)organising their activities against the Iraqi government. The positive approach of the political parties of Iraqi Kurds to the Iranian Revolution and its leadership meant that, while the KDP established direct link to the Iranian government, the PUK leader Jalal Talebani articulated the Revolution as an anti-imperialistic event benefiting the oppressed people of the region. In addition to his positive articulation of Ayatollah Khomeini, as a vanguard leader, Talebani in several attempts, through personal and open letters, offered his (party's) support and solidarity to the Revolution (van Bruinessen, 1992, pp. 37-39; Entessar, 1984).

In fact, after four decades of the establishment of the Islamic Republic in Iran, despite several peaceful initiatives of the leaders of the Iranian Kurdish movement, due to the unchanged nature and attitude of the Islamic Republic, currently the Kurdish relation to the government in Tehran is more tense than ever, because in the one hand the Kurdish socio-political and economic exclusion has reached an unseen level since the establishment of the Islamic Republic, and on the other the Iranian government approaches the Kurdish society/movement (due to their high level of politicisation and capability of mobilising collective actions) as elements of threat to Iran's political and territorial integrity.

\section{Funding Details}

The author received no financial support for the research, authorship and/or publication of this article.

\section{Acknowledgement}

I would like to thank, the editor, Dr Hasan Aydin and the two anonymous reviewers for their constructive comments on this article. 


\section{Disclosure Statement}

No potential conflict of interest was reported by the author.

\section{Biographical Note}

Dr Allan Hassaniyan obtained his $\mathrm{PhD}$ in Kurdish Studies from the Centre for Kurdish Studies at the University of Exeter. His doctoral research examined the $20^{\text {th }}$-century's Cross-border Iranian-Iraqi Kurdish Movements Interaction and effects of this interaction of the Mobilisation of the Iranian Kurdish Movement. Hassaniyan is currently a Postdoctoral Research Fellow, at the Centre for Kurdish Studies, at the University of Exeter. His research interests comprise contemporary Kurdish politics, Kurdish nationalism and national movement, civil society and political and cultural activism in Iranian Kurdistan.

\section{References}

Abrahamian, E. (1993). Khomeinism: Essays on the Islamic Republic. California, CA: University of California. Aliyar, T. (2019). "Kurdistan's oral history of left; An Interview of Mohammad Khaki with Tahir Aliyar" [in Kurdish]. Retrieved from http://m-khaki.com/video3.html

Amanat, A. (2017). Iran: A modern history. Connecticut, CT: Yale University Press.

Amjadi, S. (2011). A Review of the historic protest exodus of the people of Mariwan on its 33rd Anniversary [in Persian]. Retrieved from http://news.gooya.com/politics/archives/2011/07/125162.php

Ardelan, Y. (2015). "Interview with Yousef Ardelan on the events of the Bloody Newroz of Sanandaj" [in Kurdish]. Retrieved from https://www.youtube.com/watch?v=fVOLU08yUvM

Awad, E. M. (1984). Non-violent resistance: A strategy for the occupied territories. Journal of Palestine Studies, $13(4), 22-36$

BBC HardTalk (2015). "Interview with Sheikh Ezzedin Hosseini" [in Persian]. Retrieved from https://www.youtube.com/watch?v=_o1vu3jhe5U

Beverley, J. (1999). Subalternity and representation: Arguments in cultural theory. Durham, England: Duke University Press.

Bhat, A. (2019). Islamic Philosophy of Education. Journal of Culture and Values in Education, 2(2), 73-76. Retrieved from https://cultureandvalues.org/index.php/JCV/article/view/20

Elling, R. (2013). Minorities in Iran: Nationalism and ethnicity after Khomeini. London, England: Palgrave MacMillan.

Entessar, N. (1984). The Kurds in post-revolutionary Iran and Iraq. Third World Quarterly, 6(4), 911-933.

Entessar, N. (2009). Kurdish politics in the Middle East. Maryland, MD: Lexington Books.

Entessar, N. (2014). Between a rock and a hard place: The Kurdish dilemma in Iran. In D. Romano \& M. Gurses (Eds.), Conflict, democratization, and the Kurds in the Middle East Turkey, Iran, Iraq, and Syria (pp. 211-224). New York, NY: Palgrave Macmillan.

Entessar, N. (1992). Kurdish ethnonationalism. Colorado, CO: Lynne Rienner Publication.

Faltis, C. (2014). Toward a Race Radical Vision of Bilingual Education for Kurdish Users in Turkey: A Commentary. Journal of Ethnic and Cultural Studies, 1(1), 1-5.

Gelawej, A. (1983). Kurdistan's land relation, collapse of the tribal system [in Persian]. Tehran, Iran: Rozbeh Publication.

Ghamari-Tabrizi, B. (2016). Foucault in Iran: Islamic revolution after the enlightenment. Minnesota, MN: University of Minnesota Press.

Golperiyan, A. (2014). History of an era: A review of the political activity in Kurdistan [in Persian]. Retrieved from http://www.azadi-b.com/F-Album/tarix.y.d.abdol.g.pdf

James, K. (2019). The Stagnation, fall and rise of Singapore's Political Opposition, 1996-2013. American Journal of Qualitative Research, 3(1), 37-56. https://doi.org/10.29333/ajqr/5810

Hassaniyan, A. (2019a). The Kurdish peasant movement (1952-1953): A missing element of the Iranian Kurdish struggle. Asian Journal of Middle Eastern and Islamic Studies, 13(3), 387- 406.

Hassaniyan, A. (2019b). Cross-border Kurdish solidarity: An endangered aspect of Kurdishness. Kurdish Studies, 7(2), 135 - 160, DOI: https://doi.org/10.33182/ks.v7i2.484

Hisami, K. (1971). The martyrs of Iranian Kurdistan [in Kurdish]. Erbil, Iraq: Benkayi Peshewa.

IHRDC. (2011). Haunting memories: Executions of the Kurds by the Islamic Republic in Iran. Retrieved from http://www.iranhrdc.org/english/human-rights-documents/3507-1979-newspapers.html

Kaveh, S. (1996). Looking back in time: Recapture those memories of involvement with the KDPI [in Kurdish]. Stockholm, Sweden: Unspecified Publication.

Keddie, N. (2003). Modern Iran, roots and results of revolution. London, England: Yale University Press. 
Khosravi, J., Aghapouri, H., \& Hamehmorad, L. (2016). The Islamist Maktab-Quran in Iran and Its Challenges for Kurdish Nationalism. Journal of Ethnic and Cultural Studies, 3(1), 59-73.

Khoshhali, B. (2008a). Doctor Abdulrahman Ghassemlou and Kurdistan [in Persian]. Retrieved from https://www.iran-archive.com/sites/default/files/sanad/gunagun-ketab-Akhbar_Kurdestan_01.pdf

Khoshhali, B. (2008b). Kurdistan democratic party [of Iran] and the revolution [in Persian]. Retrieved from https://www.iran-archive.com/sites/default/files/sanad/gunagun-ketab-Akhbar_Kurdestan_02.pdf

Khoshhali, B. (2008c). Sheikh Ezzedin Hosseini and Kurdistan [in Persian]. Retrieved from https://www.iranarchive.com/sites/default/files/sanad/gunagun-ketab-Akhbar_Kurdestan_04.pdf

Khoshhali, B. (2008d). Allame Ahmad Moftizadeh and Kurdistan [in Persian]. Retrieved from https://www.iranarchive.com/sites/default/files/sanad/gunagun-ketab-Akhbar_Kurdestan_05.pdf

Khoshhali, B. (2008e). The provisional government and Kurdistan [in Persian]. Retrieved from https://www.iranarchive.com/sites/default/files/sanad/gunagun-ketab-Akhbar_Kurdestan_08.pdf

Khoshhali, B. (2008f). Qarne and the revolution [in Persian]. Retrieved from https://www.iranarchive.com/sites/default/files/sanad/gunagun-ketab-Akhbar_Kurdestan_09.pdf

Khoshhali, B. (2008g). The Kurds of Centre [Tehran] and the revolution [in Persian]. Retrieved from https://www.iran-archive.com/sites/default/files/sanad/gunagun-ketab-Akhbar_Kurdestan_17.pdf

Khoshhali, B. (2008h). Collection of essays [in Persian]. Retrieved from https://www.iranarchive.com/sites/default/files/sanad/gunagun-ketab-Akhbar_Kurdestan_20.pdf

Khoshpeyam, A. (2019). "Kurdistan's oral history of left, An interview of Mohammad Khaki with Abudallah Khoshpeyam" [in Kurdish]. Retrieved from http://m-khaki.com/video3.html

Khosravi, J., Aghapouri, H., \& Hamehmorad, L. (2016). The Islamist Maktab-Quran in Iran and its challenges for Kurdish nationalism. Journal of Ethnic and Cultural Studies, 3(1), 59-73.

Kolaqochi, F. (2015). The history of the city and neighbourhood councils in Sanandaj [in Persian]. Retrieved from http://azadi-b.com/F-Album/Fati_Kolaqochi.html

Kreyenbroek, P. \& Sperl, S. (Eds.). (2010). The Kurds: A contemporary overview. London, England: Routledge.

Mahbobi, S. (2017). Me and the butcher of Kurdistan and his daughter Fatema Sadeqhi Kalkhali [in Persian]. Retrieved from https://rowzane.com/content/shiva/article $=97950$

McAdam, D., McCarthy, J., \& Zald, M. (1996). Comparative perspectives on social movements: Political opportunities, mobilizing structures, and cultural framings. Cambridge, England: Cambridge University Press.

Milani, M. M. (1994). The making of Iran's Islamic revolution, From monarchy to Islamic republic. New York, NY: Westview Press.

Mofidi, S. (2016). The left movement and national question: From romanticism to realism (With a focus on Komala Organization). Journal of Ethnic and Cultural Studies, 3(1), 20-48.

Mohajer, N. (2014). The 18 August 1980 [in Persian]. Retrieved from https://www.radiozamaneh.com/92204

Mohséni, C. (2018). The instrumentalization of ethnic conflict by the state: The Azeri-Kurdish conflict in Iran. In G. Dorronsoro \& O. Grojean (Eds.), Identity, conflict and politics in Turkey, Iran and Pakistan (pp. 217 232). London, England: Oxford University Press.

Moradbeigi, H. (2004). Living history: Kurdistan, the left and nationalism [in Persian]. Stockholm, Sweden: Nasim.

Mostafa Sultani, R. (2006). Kak Foad, leader, politician and a political thinker [in Persian]. Selimani, Iraq: Rojhelat Publication.

Mustafa Sultani, M., \& Watandust, S. (2015). Kak Foad Mostafa Sultani; Who was he, what was his aim and how did he die? [in Persian]. Sulaimaniya, Iraq: Piramerd.

Nesrollabaegi, A. (2011). The bloody Newroz of Sanandaj [in Persian]. Retrieved from http://komalah.org/Farsi/index.php/didgah/4558.html

Nikraftar, K. (2017). Paweh's five days war [in Persian]. Retrieved from https://kiumarce.com/main/wpcontent/uploads/2017/08/jangeh-paveh-v2-2-1.pdf

Phillips, L. D. (2019). The great betrayal: How America abandoned the Kurds and lost the Middle East. London, England: I.B. Tauris.

Randle, M. (1994). Civil resistance. California, CA: Fontana Press.

Roberts, A. (2009). Introduction. In A. Roberts \& T. Garton (Eds.), Civil resistance and power politics: The experience of non-violent action from Gandhi to the present (pp. 1-24). Oxford, England: Oxford University Press.

Romano, D. (2006). The Kurdish nationalist movement: Opportunity, mobilization, and identity. Cambridge, England: Cambridge University Press.

Saheb, S. R. (2017). 19 August: The anniversary of the attack of the people of Kurdistan [in Kurdish]. Retrieved from http://www.komala.org/farsy/drejawtar.aspx?NusarID=4\&Jmara=7

Seyedi, H. (2018). The bloody Newroz of Sanandaj [in Persian]. Retrieved from https://soundcloud.com/hemnseyedi/5hhbjqr4kpqc 
Shams, S. (2006). Nationalism, political Islam and the Kurdish question in Iran, reflection on the rise and spread of political Islam in Iran. Berlin, Germany: VDM Verlag.

Sharifi, M. (2013). Imagining Iran, the tragedy of subaltern nationalism. Maryland, MD: Lexington Books.

Tehran Musavvar. (1979a). Digital Iranian history, Nashriyah: The University of Manchester. Retrieved from https://bit.ly/2MgehI4

Tehran Musavvar. (1979b). Digital Iranian history, Nashriyah: The University of Manchester. Retrieved from https://bit.ly/2McPHIm

Tehran Musavvar. (1979c). Digital Iranian history, Nashriyah: The University of Manchester. Retrieved from https://bit.ly/33xoUfo

Tehran Musavvar. (1979d). Digital Iranian history, Nashriyah: The University of Manchester. Retrieved from https://bit.ly/2oI9KVX

Tehran Musavvar. (1979e). Digital Iranian history, Nashriyah: The University of Manchester. Retrieved from https://bit.ly/2owbNwv

Tehran Musavvar. (1979f). Digital Iranian history, Nashriyah: The University of Manchester. Retrieved from https://bit.ly/35x7f9J

Tehran Musavvar. (1979g). Digital Iranian history, Nashriyah: The University of Manchester. Retrieved from https://bit.ly/2OVWhov

Thomassen, B. (2012). Notes towards an anthropology of political revolutions. Comparative Studies in Society and History, 54(3), pp. 679-706.

Tilly, C. (1978). From mobilization to revolution. New York, NY: Random House.

Tolba, N. (2018). From Rebellion to Riots. Research in Social Sciences and Technology, 3(2), 93-114. Retrieved from https://ressat.org/index.php/ressat/article/view/358

Vali, A. (2016). Reflections on Kurdish society and politics in Rojhelat. In M. Gunter (Ed.), Kurdish issues: Essays in honor of Robert W. Olson (pp. 283-314). Costa Mesa, CA: Mazda Publishers.

van Bruinessen, M. (1992). Agha, Sheikh and state: The social and political structures of Kurdistan. London, England: Zed Books. 